\title{
PLURAL CONCEPTIONS OF INTEGRATION OF SCIENCE AND RELIGION
}

\author{
Zulkifli*, Cucu Nurhayati, Bambang Ruswandi, Fadhilah Suralaga \\ Syarif Hidayatullah State Islamic University of Jakarta, Indonesia \\ E-mail: zulkifli@uinjkt.ac.id
}

Received: $25^{\text {th }}$ July 2020; Revised: $14^{\text {th }}$ November 2020; Accepted: $28^{\text {th }}$ December 2020

\begin{abstract}
Along with the transformation of Islamic higher educations into full-fledged universities, the concept of integration of science and religion is their key characteristic. Indonesian education has witnessed the dynamic and development of paradigm, concept, and metaphor for Islamic university's science integration. Many studies dealing with the paradigm and concept of science integration and its implementation in curriculum design and learning process have been conducted but tend to focus on the monolithic understanding of each university. By distancing itself from the general trend, this study attempted to analyze the plural conceptions of science integration and factors affecting the plural conceptions at UIN Syarif Hidayatullah Jakarta. To achieve the goal, we employed a mixed method of quantitative and qualitative approach with questionnaires distributed to the sample of 147 lecturers, focus group discussion with 25 participants, and library studies. The study found that three types of conceptions have developed and co-existed at UIN Syarif Hidayatullah Jakarta, namely official conception, senior academia's conception, and general lecturers' conception. Each has its formulation and emphasis, although they share some similarities. The study also revealed the institutional factor as context and individual factors, mainly experience and expertise, resulting in the plural conceptions of science integration. Thus, the concept of science integration at an Islamic university should be considered as a dynamic and plural entity.
\end{abstract}

Keywords: science integration; conception; experience; expertise

\section{Abstrak}

Seiring dengan transformasi perguruan tinggi keagamaan Islam menjadi universitas penuh, konsep integrasi ilmu dan agama menjadi karakteristik utamanya, dan pendidikan Indonesia telah menyaksikan dinamika dan pengembangan paradigma, konsep, dan metafora integrasi ilmu di universitas-universitas Islam tersebut. Banyak penelitian yang berhubungan dengan paradigma dan konsep integrasi ilmu serta implementasinya dalam desain kurikulum dan proses pembelajaran telah dilakukan, tetapi penelitian-penelitian tersebut cenderung berfokus pada pemahaman monolitik dari masing-masing universitas. Berbeda dengan itu semua, penelitian ini berusaha menganalisis beragam konsepsi tentang integrasi ilmu dan agama dan faktor-faktor yang mempengaruhi beragam konsepsi tersebut di UIN Syarif Hidayatullah Jakarta. Kami menggunakan metode campuran kuantitatif dan kualitatif dengan teknik kuesioner yang disebarkan kepada 147 responden, Focus Group Discussion dengan 25 partisipan, dan studi kepustakaan. Studi ini menemukan bahwa tiga jenis konsepsi telah berkembang dan hidup berdampingan di UIN Syarif Hidayatullah Jakarta, yaitu konsepsi resmi, konsepsi akademisi senior, dan konsepsi dosen umum. Masing-masing memiliki rumusan dan penekanan sendiri meskipun mereka memiliki beberapa kesamaan. Studi ini juga mengungkapkan faktor kelembagaan sebagai konteks dan faktor individu terutama pengalaman dan keahlian yang mempengaruhi beragam konsepsi integrasi ilmu. Dengan demikian, konsep integrasi ilmu di universitas Islam harus dipahami sebagai entitas yang dinamis dan beragam.

Kata kunci: integrasi sains; konsepsi; pengalaman; keahlian

How to Cite: Zulkifli, Nurhayati, C., Ruswandi, B., Suralaga, F. (2020). Plural Conceptions of Integration of Science and Religion. TARBIYA: Journal of Education in Muslim Society, 7(2), 142-157. doi:10.15408/tjems.v7i2.18991.

Permalink/DOI: http://doi.org/10.15408/tjems.v7i2.18991 


\section{Introduction}

The concept of integration of science and religion has become an essential topic of discussion in the Muslim world in general (Bigliardi, 2014; Çoruh, 2020) and in Indonesia in particular (Azra, 2013; Abdullah, 2014). It has raised heated debates among scholars and the transformation of Indonesia's Islamic higher educational institutions into full-fledged universities that have reached 17 Islamic universities throughout Indonesia because it becomes the key characteristic of Islamic universities, which distinguishes them from the existing public universities. Since then, each Islamic university has formulated its paradigm, concept, and metaphor for integrating science and religion as the philosophical and academic basis for the advancement of knowledge and institutions. Apart from the importance of the concept of science-religion integration, however, the directorate general of Islamic education, the Ministry of Religious Affairs, has just issued the guidelines for the implementation of sciencereligion integration at Islamic religious higher educations on May, 2019.

There are at least three paradigms of integration of science and religion: Islamization of science, the 'scientification' of Islam, and open and dialogic integration. Many studies have been devoted regarding the integration of science and religion formulated or used by Indonesia's state Islamic universities, especially their paradigm (Miftahuddin, 2016; Darda, 2015; Nata, 2019) and its implementation in curriculum development (Miftahuddin, 2019), and learning process (Fanani, Solokhan, \& Karnadi, 2014; , Fauzan, \& Sayuti, 2018; Sayuti \& Rahiem, 2020). Some researchers like Akbarizan (2014) focus on its implementation of integration of science in Islamic universities, while others such as Siregar (2014), Naim (2018), and Iswantir (2018) concentrate on intellectual figure's thought of science integration of Amin Abdullah,
Mulyadhi Kartanegara, Azyumardi Azra respectively. Regarding the paradigm aspect, while Miftahuddin (2016), Miftahuddin (2019) and Hanifah (2018) conclude that UIN Syarif Hidayatullah Jakarta (thereafter, UIN Jakarta) has used an open and dialogic paradigm, Darda (2015) in his plain analysis considers it mechanical paradigm. All studies above see the monolithic understanding of paradigm and concept of science integration at each Indonesian Islamic university and therefore it needs to be proportionally criticized. Concerning Islamization of science paradigm, which has also been widely discussed, has been formally implemented by International Islamic University Malaysia (IIUM), but, in fact, "[ $\mathrm{t}]$ here are different conceptions of Islamization at IIUM and they have co-existed" (Hashim \& Abdallah, 2013). Inspired by the phenomenon of IIUM and unlike the monolithic tendency of previous studies, this article is aimed at analyzing the plural conceptions of integration of science and religion and the factors influencing the plural conceptions at UIN Syarif Hidayatullah Jakarta.

\section{Method}

This study used a mixed-method that combined quantitative and qualitative approaches implementing transformative mixed method procedures to obtain a comprehensive analysis of the conception of the science-religion integration at UIN Jakarta. In this study, which was conducted in 2019, the research subject was UIN Jakarta's lecturers from twelve faculties and the graduate school; One hundred forty-seven respondents, which consisted of 76 female and 71 male lecturers as sampling in the study using simple random sampling. To collect the required data, the researchers asked the lecturers to fill out questionnaires about their perceptions about the integration of science and religion and factors influencing the conceptions. 
To evaluate the instrument's quality, we assess the validity and reliability of the pilot survey questionnaire. The result of the assessment can be seen in table 1 .

Table 1. The Result of Validity and Reliability of Pilot Survey

\begin{tabular}{llllll}
\hline Construct & Item & $\boldsymbol{r}$ & Result & $\begin{array}{l}\text { Alpha } \\
\text { Cronb } \\
\text { ach's }\end{array}$ & Result \\
& & & & & \\
Perception & B1 & 0.383 & Valid & 0.823 & Reliable \\
of Science- & B2 & 0.579 & Valid & & \\
Religion & B3 & 0.697 & Valid & & \\
Integration & B4 & 0.655 & Valid & & \\
& B5 & 0.717 & Valid & & \\
& B6 & 0.601 & Valid & & \\
& B7 & 0.476 & Valid & & \\
\hline
\end{tabular}

As shown in Table 1, the test result of validity shows that all items used to measure the perception of the integration of science and religion have a value of $r>0.3$. Thus, they all are valid. Similarly, concerning the reliability, we found the value alpha Cronbach's higher than 0.7 so that all items are reliable and have high consistency. This means that all questionnaire items can be used in the data collection process (Kaplan \& Saccuzzo, 2005).

The research techniques used to obtain qualitative data include focus group discussion and library research. The focus group discussion was conducted with 25 lecturers who taught the subject of Islam and Science to uncover their perception and understanding of science and religion's integration. Included in the library research was collecting documents to obtain data relating to the university's official policies and works on the concept and implementation of science integration at UIN Jakarta. All qualitative and quantitative data were processed and analyzed quantitatively and qualitatively. Qualitative data were analyzed using Miles and Huberman's model, namely data reduction, data display, data verification, and conclusion. Quantitative data analysis used descriptive statistics to see the frequency of each respondent's response regarding the conception and Chi-Square correlation to examine factors affecting the conceptions of integrating science and religion.

\section{Results and Discussion}

\section{Plural Conceptions}

Similar to the different conceptions of Islamization of science at IIUM (Hashim \& Abdallah, 2013), there have been plural conceptions of integration of science and religion at UIN Jakarta. The first is the official conception. As stated in its statute, the transformation of IAIN into UIN is meant to fulfil its vision; "to become a world-class university with the excellence in the integration of science, Islamic teachings, and Indonesian values." To achieve the vision, one of its missions is written as: "reintegrating science at the level of ontology, epistemology, and axiology so that there is no more dichotomy between general and religious sciences." From this official document (Peraturan Menteri Agama, 2014), it is evident that the concept of integration of science used at UIN Jakarta means reintegration to erase the dichotomy between modern or general science and religious science. This is the official model of integration of science at this university.

The rector of the university Azyumardi Azra (1998-2006), clearly emphasized that the integration of science is the reintegration of the current dichotomous development of modern science. The term reintegration implies to reunite what has existed in history. Abuddin Nata, Masykuri Abdillah, Suwito, and Armai Arief elaborated the concept of integration of science and Islam and emphasized its foundation at the level of anthology, epistemology, and axiology. The integration has sound theological, historical, and philosophical bases, and Islam does not recognize the dichotomy between general and religious sciences. "Both are bound by the principle of tawhid, a principle which sees that 
ontological, epistemological, and axiological aspects are the same" (Nata et al., 2003). Islamic history also proved the integrated development of science, as evidenced in the figure of Avicenna, Averroes, and Ibn Khaldun (Nata et al., 2003). The then rector and the team explicitly reject the integration of science and religion as an Islamization of science but rather a recognition of science and religion that may become the basis for developing new disciplines.

The conceptualization of science integration during the rectorial period of Komaruddin Hidayat (2006-2015) might be expressed in the famous motto knowledge, piety, and integrity, which has been used as the university's core values. Knowledge indicates that UIN Jakarta places the achievement of knowledge as the key point. It also means that UIN Jakarta commits to advance all groups of science, namely natural sciences, social sciences, religious sciences, the humanities, formal sciences, and applied sciences, from the integrated perspective in the framework of producing intelligent, creative, and innovative human resources from the Muslim community in order for them to participate in the national and global development. This can only be achieved through processes of learning, discovery, and engagement. Piety means that UIN Jakarta commits to establishing the quality of piety, both personal and social, which becomes the basis for social interaction. With piety, UIN Jakarta maintains an open attitude in interpersonal, intrapersonal, and social relations. Integrity means that UIN Jakarta has committed to establishing integrated personality upholding ethics and civic values in daily life, and having confidence and respect for others (Keputusan Direktur Jenderal Pendidikan Islam, 2019). With the core values, UIN Jakarta maintains to produce alumni having the depth and breadth of knowledge, sincerity and piety, and integrated personality in order to implement the vision of integration of science, Islamic teachings, and Indonesian values.

The formalization of practical policy and implementation regarding the integration of science was formulated during the rectorial period of Dede Rosyada (2015-2019). After a series of meeting at the university senate, the then rector Prof. Dede Rosyada issued guidelines to pursue the integration of science in the rectorial decision number 864 of December 2017, which states: (1) The integration of science is the unification of Islamic religious sciences with other sciences so that these sciences are not conflicting and dichotomous; (2) the integration of science referred to in paragraph (1) is different from the Islamization of science. This is an attempt to clarify the concept of integration and policies that the university authority and academia must implement the integration of science at the university. It is clearly stated that the integration of science is not an Islamization of science.

In the implementation, the guidelines outline six groups of science and technology: religious sciences, the humanities, social sciences, natural sciences, formal sciences, and applied sciences. The integration of religious sciences and other groups of sciences may take specific steps or forms, such as taking certain groups of sciences as a reference for dialogue, supporting arguments, a source of inspiration, a perspective, or an object to which religious values are integrated. The guidelines also state that the integration strategies include strengthening general sciences relevant to the group of religious sciences and strengthening religious sciences for the group of general sciences. Besides, the implementation of science integration is an obligation of all university elements, including lecturers, institutes, and the rector (Keputusan Rektor UIN Syarif Hidayatullah Jakarta, 2017).

There are at least six points that characterize UIN Jakarta's formal conception of integration 
of science: first, integration means reintegration or unification; second, its rejection of Islamization of science, as promoted by certain Muslim scholars and institutions; third, its rejection of dichotomy and conflicting relation between sciences; fourth, its rejection of using metaphor to the concept, as used by UIN Yogyakarta, UIN Malang, UIN Bandung, UIN Surabaya and others. On the use of metaphor in formulating the integration of science, Abuddin Nata writes:

Amin Abdullah's conception of scientific integration with the metaphor of spider web is now no longer heard [and] has been abandoned along with the completion of the initiator's task as rector. The spider web has not succeeded in capturing spiders; it has not been connected with all education components, especially the curriculum, teaching and learning process, infrastructure, culture and academic traditions, etc. Likewise, the integration of science with the metaphor of the tree of science as initiated by Imam Suprayogo, its fate is also the same as the spider web initiated by Amin Abdullah. The idea of scientific integration with the Tree of Science is no longer cared for, nurtured, and watered, so it is almost forgotten and has not produced fruits that can be enjoyed. Likewise, the integration of science through Nanat Fatah Natsir's wheel metaphor has the same fate as Amin Abdullah's spider web, and Imam Suprayogo's the Tree of Science. The wheel no longer spins; no one looks after it and is stuck (Nata, 2019).

Fifth, the integration of science and religion is a never-ending process. "I thought the integration of science does not finish yet," said Azyumardi Azra at a Round Table Discussion on March 12, 2019. For UIN Jakarta, the integration of science and religion is not a final product. "UIN Jakarta does not see integration as an end but a process. What UIN Jakarta thinks more is not what form of integration-- such as spider, tree, cart, flower or whatever-- but rather how the integration process can be carried out" (Jabali \& Khitam, 2014). The process is more important than the result, and every academia is engaged in a scientific and academic process to discuss, debate, and formulate the integration of science. This is closely related to the sixth characteristic, namely, its open and dialogic paradigm (Miftahuddin, 2019). It is an open and critical worldview that respects the existence of the types of science, general and religious sciences, proportionally. Not only do they coexist, but they can also be interacted and mutually criticized constructively (Kusmana et al., 2006). It is generally agreed that the pioneer of the open and dialogic paradigm was the late Harun Nasution, who has exerted significant influence in the development of the academic and intellectual life of the university. He has promoted the vital position of reason and revelation in developing general sciences and religious sciences that should be integrated. Reason and revelation should be synergized in order to gain truth (Kusmana et al, 2006).

Table 2. UIN Jakarta's Concept and policy of Science Integration are open and dialogic

\begin{tabular}{llll} 
No & Category & Frequency & Percentage \\
$\mathbf{1}$ & $\begin{array}{l}\text { Strongly } \\
\text { disagree }\end{array}$ & 2 & $1.4 \%$ \\
2 & Disagree & 7 & $4.8 \%$ \\
3 & Agree & 87 & $59.2 \%$ \\
$\mathbf{4}$ & Strongly agree & 51 & $34.7 \%$ \\
\multicolumn{7}{l}{ Total } & $\mathbf{1 4 7}$ & $\mathbf{1 0 0 \%}$
\end{tabular}

Based on table 2, nearly all UIN lecturers $(93.9 \%)$ recognize that the integration of science and religion at the university is open and dialogic. This means that they see the integration of science and religion as an open-ended and dialogic process in which academia is allowed to discuss, debate continuously, and formulate it; UIN Jakarta neither considers the form of 
integration nor the metaphor for integration, but rather the integration process to be carried out. Atho Mudzhar emphasizes that UIN Jakarta "did not advocate any need for metaphors on the integration of science and religion" (2018). Each faculty, department, and people are allowed to formulate knowledge based on his/her understanding and experience. Diversity of understanding and experience will produce various integration models, and all of them may exist at UIN Jakarta. In this regard, many kinds of scientific activities that attracted senior professors and young lecturers have been conducted to discuss, debate, and formulate the philosophical and practical aspects of integrating science and religion at UIN Jakarta.

The second type of conception is seen from common lecturers, as shown in the survey and the focus group discussion. Here, there is a tendency to perceive the integration of science and religion as an Islamization of science among lecturers, although the university's official standing explicitly rejects such a conception. More than half of them perceived it as an Islamization of science, whilst others rejected it. It can be seen from Table 3 that the number of lecturers who agree with the integration of science as an Islamization of science is $55.8 \%$ (consisting of $35.4 \%$ agree and $20.4 \%$ strongly agree) while $44.2 \%$ of them $(35.4 \%$ agree and $8.8 \%$ strongly agree) reject the conception. The data show that most lecturers hold the conception of science's integration as an Islamization of science. As a comparison, this finding is similar to the fact that "there are still many IIUM lecturers who are unclear about the Islamization and Integration agenda" (Hashim \& Abdallah, 2013).

During our FGD, a lecturer states clearly that the original problem of integration of science and religion is that science needs Islamizing, and this should start from the inculcating tawhid (unity of God) in students or lecturers. It is also emphasized that to integrate science and religion, one needs to have a robust Islamic philosophy foundation. One cannot just relate the cosmic verses to the Qur'anic verses without having firm tawhid awareness followed by purifying oneself from sins and flawed characters. Included in it is the integration in the form of attitude and behaviour. With tawhid as the foundation, one will view that general science is Islamic science.

Table 3.Integration of science is an Islamization of science

\begin{tabular}{llll} 
No & Category & Frequency & Percentage \\
$\mathbf{1}$ & $\begin{array}{l}\text { Strongly } \\
\text { disagree }\end{array}$ & 13 & $8.8 \%$ \\
$\mathbf{2}$ & Disagree & 52 & $35.4 \%$ \\
$\mathbf{3}$ & Agree & 52 & $35.4 \%$ \\
$\mathbf{4}$ & Strongly agree & 30 & $20.4 \%$ \\
\multicolumn{2}{l}{ Total } & $\mathbf{1 4 7}$ & $\mathbf{1 0 0 \%}$
\end{tabular}

As a consequence of the open and dialogic paradigm, in the Round Table Discussion of professors on the integration of science on March 12, 2019, we reveal the varied forms of integration at UIN Jakarta, from the minimum form to the ultimate form. They are recognized as legitimate in the sense of a never-ended process of integration. The minimum form might be the use of Quranic verses relevant to topics taught or analyzed. Another form is related to its manifestation in religious attitude, practice, and behaviour of students and lecturers in which they can recite the Qur'anic verses, lead communal prayers, read sermons and others, in addition to having noble attitude and morality without relying on the aspect of epistemology or philosophy in the integration of science. In other words, it is a manifestation of knowledge, piety, and integrity. Thus, this has revealed varied conceptions of integration of science at UIN Jakarta.

Concerning the Islamization of science, a note should be made that it has become an international intellectual movement among 
Muslim scholars since the late 1970s. The concept was first used and proposed by Muhammad Naquib Al-Attas in 1978 and then promoted by Ismail Raji al-Faruqi in 1982. For these figures, science needs to be Islamized because of the assumption that modern science has kept away from religion and brought about destructive impacts on the human being. The project of science Islamization was implemented by establishing the International Institute of Islamic Thought (IIIT) in Herndon, America. Other universities with the similar vision include the International Institute of Islamic Thought and Civilization (ISTAC), International Islamic University Malaysia, both in Kuala Lumpur, and International Islamic University Pakistan in Islamabad (Muslih, 2006; Ahsan, Shahed, \& Ahmad, 2013; Hashim \& Abdallah, 2013; Obaidullah, 2010; Abdallah, Huseein, \& Hisham, 2011).

The third type of conception comes from senior professors as intellectual figures. As mentioned previously, Azyumardi Azra's conception of integration of science is understood as reintegration. "The reconciliation and reintegration between the two groups of science-sciences that derived from the Qur'anic verses and those derived from the Cosmic verses-means the return to the transcendental unity of all sciences" (Azra, 2005). Like other UIN Jakarta's senior professors, Azyumardi Azra explicitly rejects the idea of Islamization of knowledge, and UIN Jakarta does not adopt this paradigm in its institutional transformation.

Again, from the UIN Jakarta perspective, the idea of 'Islamization of knowledge' is, to a large extent, questionable since all knowledge and sciences are already Islamic. Natural sciences are, of course already based on universal principles; while if certain theories in social sciences and humanities are mostly Westernbased, then the need is not to 'Islamize' them, but to develop theories that are based on Muslim social and cultural realities (Azra, 2013).

He emphasizes that the concept of reintegration of science at UIN Jakarta is formulated at three levels: first, at the level of philosophy and epistemology, second, at the level of curriculum, and third, at the faculty level and academic programs.

At a more philosophical level, at least in UIN Jakarta, the IAIN conversion to UIN is based on the reintegration of the so-called Islamic religious sciences and 'secular' sciences. There is no need to discuss the origins of this dichotomy in the history of knowledge in Islam. What is important is from the UIN Jakarta perspective is that all sciences epistemologically come from God, the All-Knowledgeable, through the 'ayat Qur'aniyyah' (Qur'anic verses) and the 'ayat kawniyah', the signs of God that are spread all over the universe. Muslims needs to learn the 'ayat Qur'aniyyah' and the 'ayat kawniyyah' at the same time, since through the study of the two ayats, Muslims will be able to acquire various kind of knowledge and sciences that are necessary for their lives (Azra, 2013).

It is advisable to pinpoint that with the scientific renewal of reintegration of science, UIN Jakarta was indeed established as a strategic step to erase the dichotomy between religious sciences and general sciences and as a manifestation of the integrative model between science and religion. "This integration is based on faith, knowledge, and good deeds. The paradigm of scientific integration is the basis for the university's development so that it can contribute significantly to the progress of social development of the nation" (Azra, 2005).

At UIN Jakarta, Mulyadhi Kartanegara's conception of integration of science and religion is mystical-philosophical, focusing on scientific 
integration's epistemological foundation (Naim, 2018). Therefore, Kusmana (2014) considers his conception is close to an Islamization of science, although he does not advocate the term. Like other thinkers, he argues that modern science itself has resulted in severe problems both scientifically and religiously while attempting to provide an epistemological foundation for the mastery of science, namely the doctrine of tawhid (unity of God) as formulated philosophers and Sufis. On the tawhid as the epistemological foundation of scientific integration, Kartanegara's conception is the same as Muhammad Naquib al-Attas's (Hidayat, 2017).

For Kartanegara, in response to the existing dichotomy of modern sciences, the integration or reintegration of science should be directed to formulate a holistic integration of science and religion based on tawhid. He explicitly states to use Mulla Sadra's conception of wahdat al-wujud (unity of existence). Based on Mulla Sadra's conception of tawhid, he pinpoints the existence of the metaphysical realm or the physical realm's inner dimension while criticizing the modern understanding of science only focused on physical reality as advocated by Emanuel Kant, August Comte and others. Therefore, he proposes the integration of science from several aspects: object, sources, classification, and method. Since the objects of science include the physical and metaphysical realm, science should not be limited only to empirical research using the experimental (tajribi) method as maintained in modern science, but also burhani (demonstrative), bayani (textual), and irfani (intuitive) methods. Another vital aspect of Kartanegara's thought on integrating science is the scientific aspect of ilmu khuduri (presential knowledge or knowledge by presence), although it differs from ilmu khusuli (acquired knowledge). He writes:

If in the research of sensed objects observation method or experiment must be assisted with measurement system and additional instrument, rational identification must be gained by introducing and implementing strict logic rules, the way people gain presential knowledge is by isti'dad, namely preparing to meet illumination (lighting) directly from God... by purifying ... our (hearts) from all dirt or sin and stains...the lens of our hearts must be kept clean and subtle. That is why the remembering of God that is essentially erasing every shirk dust from our hearts and tazkyah al-nufus (self-cleansing especially from egocentrism) becomes very important in our efforts to get to know objects that are present in us. Thus, it is not the cultivation of senses or reason that is important here, but mental or spiritual cultivation, as practised by pious people, including prophets and saints, or as we see in spiritual practices (riyadah al-nafs) carried out in Sufi orders (Kartanegara, 2005).

In short, to integrate science and religion is to find the same basis for science regarding sources and methods, namely experimental, demonstrative, textual, and intuitive methods integrated holistically in the so-called Islamic epistemology. He writes: "Combining two different sets of science, secular and religious, in an educational institution as has happened so far without being followed by epistemological construction is an effort that will not produce integration but will only be like gathering in the same space two separate entities" (Kartanegara, 2005). To achieve holistic epistemological integration, attempts should be directed at least three levels: ontological integration, integration of scientific classification, and methodological integration. Like Azyumardi Azra, he seems to prefer the term reintegration of science by reconstructing "an epistemological system that is coveted and may be more suitable for our 
religious tertiary institution, like our beloved UIN” (Kartanegara, 2005).

Criticizing the paradigms and metaphors of integrating general sciences and religious sciences conceptualized by most state Islamic universities in Indonesia, M. Atho Mudzhar offers his view focusing on the differences between natural sciences and the humanities and social sciences in which religious values can be integrated. He points out five possible relationships or paradigms between science and religion: conflict, mutually independent relationship, Islamization relationship, dialogical relationship, and integrational relationship (2018). He explicitly rejects the conception of Islamization of science and the use of metaphors to explain the integration because they lack conceptual clarity, particularly in terms of the different characteristics and degrees of the vulnerability of natural sciences, social sciences, and the humanities to values. In this regard, Atho Mudzhar emphasizes that the integration of science and religion is actually "the question of attaching values to science" (2018). "Since Islam is a body of doctrine and values, the integration of science and Islam is a question of integration of science and Islamic values.... it must be noted here that science is never free of values, although particular sciences are more accessible than others. Particular sciences may be value-free at certain stages, but not at all stages" (Mudzhar, 2018).

For Atho Mudzhar, another strategy of integration is the reconstruction of core and auxiliary sciences. Certain types of science may be developed either as a core subject or as an auxiliary discipline in explaining specific related issues or positioned vice versa. This will, in turn, constitute new separate disciplines. Furthermore, he proposes the strategy of the two-way direction of integration: first, as mentioned above, the integration of certain types of science to values in various degrees; second, the integration of natural sciences, social sciences, and the humanities as auxiliary subjects to the core subjects of religious studies. The inclusion of subjects such as sociology, anthropology, philosophy, management, history, archaeology, and research methodology in the curriculum of departments within the faculties of conventional Islamic studies is an example of the second integration strategy (2018). Thus, Mudzhar's focus and formulation of science and religion integration differ sharply from Kartanegara's in that the former never touches the epistemological aspect.

Like Atho Mudzhar, Dede Rosyada (2016) criticizes that the concept of Islamization of science is no longer relevant because it is only based on suspicious attitude towards Western empirical theories that are considered contrary to Islamic teachings. Muslim scholars' understanding of scientific theories has been progressive. Muslim accommodation to and acceptance of various sciences has proved no dichotomy between general and religious sciences, but they are united and disembogue to God. The sources of science include God's verses and the universe (Rosyada, 2016).

In his writing on 'UIN Jakarta as a Model for the Center of Integration of Science,' Dede Rosyada affirms that the development and implementation of science and technology at UIN Jakarta has been inspired by religious spirit or theological power towards complete obedience only to God. The advancement of general sciences at UIN Jakarta and their interaction with religious sciences should have ideal goals as expected by Indonesian Muslims; namely, general sciences should be developed to understand and promote religious norms that should be practised in various professional aspects of social life. Then, general sciences should produce theories, technologies, and instruments that can be implemented in human life, originated or inspired by religious texts. 
Finally, since Islam becomes a mercy for humankind, the educational process should provide students of general science with relevant knowledge, skills, and expertise to become experts and skilled graduates capable of implementing their knowledge in varied aspects of professional, economic, and social life (Rosyada, 2016).

Like other scholars, Dede Rosyada has emphasized the urgency of the integration of science and religion. He also explains some practical strategies in implementing the integration of science and Islam. It should start from the integration through the curriculum, adopting a shared curriculum, webbed curriculum, and integrated curriculum. It should commence with curriculum development and design, learning design, practice and training until learning assessment and evaluation. Dede Rosyada also elaborates the strategy of integration of science through the syllabus, learning material, team teaching, and even learning environment.

Abuddin Nata defines integration of science, namely:

"a situation in which a science and others are not mixed so that they loose their ontological, epistemological, and axiological character, but an attempt to synergize, dialogue, communicate, and unite so that between the sciences there is a meeting point, and it is devoted not only for the sake of science itself, but in accordance with its main function, namely to give light, explanation, easiness, and guidance for mankind in answering various life phenomena" (Nata, 2019).

Like Mulyadhi Kartanegara, Abuddin Nata emphasizes faith or tawhid as the basis for the integration of science. He points out that tawhid has to become the basis for the development of science by maintaining the view that those who believe in the existence of God and admire his power should contemplate, delve, and investigate God's written verses and unwritten laws, which are included in the Quran, in the universe, in social phenomena, and even in their intuition. All of them, in turn, lead to construct varied types of science, namely natural sciences, social sciences, religious sciences, and mysticism or Sufism (Nata, 2019). Following Mulyadhi Kartanegara, he also proposes that tawhid integrates ontological, epistemological, and axiological aspects of science because he believes that; a) the source of all knowledge is God; b) all scientific methods utilizing potentials and facilities are given by God, and; c) values of science are for the benefits and prosperity of human being in order to be close to God (Nata, 2019).

Abuddin Nata (2019) appreciates that great ideas regarding the integration of science have been produced, but they lack clarity in the implementation. He does not propose a specific integration model, but he suggests that the integration of science should be implemented concretely in applicative forms. Here he follows Rosyada's view that the implementation of science can be conducted through curriculum, syllabus, team teaching, learning method and approach, evaluation, environment, and others.

In sum, three types of conception, namely official conception, intellectual figures, and lecturers, have developed and co-existed at UIN Jakarta. The official conception of integration has at least four characteristics: its rejection of an Islamization of science, its rejection of the use of metaphor, its open and dialogic paradigm, and a never-ending process. These characteristics are also in line with senior academia's conception. However, unlike the two types, some lecturers, as shown by the survey, perceive it as an Islamization of science. Apart from the official conception, which explicitly includes the element of science, Islamic teachings, and Indonesian 
values, the aspect of Indonesian values is absent in the intellectual figures' formulation. All three types agree that there is no dichotomy between general sciences and religious sciences, and the source of all sciences is God.

\section{Factors}

In this study, we tried to analyze the factors contributing to the plural conceptions of the integration of science and religion. We classify two main factors: institutional and individual factors. The institutional factor provides essential contexts for the plural conceptions of integration of science at UIN Jakarta. As has been uncovered in many studies (Rifai et al., 2014); (Sayuti \& Rahiem, 2020); (Efrinaldi \& Taufiqurrahman, 2020), the formulation of paradigm and concept of science integration and its implementation have been affected by contexts of culture and environment. Nata (2019) suggests that the integration of science promoted by UIN Jakarta is a result of the renewal of Islamic thought led by Harun Nasution with his 'rational Islam' project, which has made UIN Jakarta popularly recognized as a 'renewal campus'. Here we found successful actualisation efforts, reinterpretation, reformulation, contextualization, and transformation of Islamic thought, including science integration. Although he did not advocate the term integration, Harun Nasution has clearly emphasized that both sciences (religious and others) should be advanced at an Islamic university (Ro’up, 2019). Some essential characteristics of the renewal project include pluralism and religious moderation, which undoubtedly leads to the plural conceptions of integration of science.

Following its position and reputation, UIN Jakarta has become a miniature of Indonesian society and culture with unity in diversity. It has provided a melting pot of people from diverse ethnicities and cultures. Some professors, intellectuals, and community leaders from diverse backgrounds have been assembled at this university and played important roles in its establishment. UIN Jakarta does not belong to a particular dominant culture or ethnic group to which other groups should adapt. Everyone has the same opportunity to participate and engage in its development. This has made UIN Jakarta open, plural, and democratic and, in turn, contributes to the plural conceptions of integration of science.

Concerning the individual factor, there are experience and expertise that may influence the different conceptions. An anthropologist defines experience as "historically and culturally constituted process predicated on certain ways of being in the world" (Beck, 2015). It may include learning experience, teaching experience, or job experience. Here we examine which demographical characteristics of lecturers, including gender, educational degree, type of educational background, academic profession level, occupation status, and the duration of teaching experience as a lecturer, statistically influence the different conception of integration of science and religion. From these aspects, as shown in Table 4, only the teaching experience duration is a significant contributing factor because, from Chi-Sequare examination, PValue's result is 0.015 , which is smaller than 0.05 . This means that the longer the lecturers teach at UIN Jakarta, the less likely they perceive integration of science and religion as an Islamization of science as outlined in the Guidelines. This also means that teaching experience at UIN Jakarta in which they are engaged in discussion, seminar, conference, workshop, socialization, and other kinds of the scientific meeting will help construct their perception of integration of science and religion. 
Table 4. Factors Influencing Conception of Science Integration as Islamization

\begin{tabular}{|c|c|c|c|c|}
\hline $\begin{array}{l}\text { Teaching } \\
\text { Experience }\end{array}$ & \multicolumn{2}{|c|}{$\begin{array}{l}\text { Science Integration } \\
\text { as Islamization }\end{array}$} & $\begin{array}{l}\text { Chi- } \\
\text { Square }\end{array}$ & $\begin{array}{l}\text { P- } \\
\text { Value }\end{array}$ \\
\hline & Disagre & Agree & & \\
\hline$<1$ Years & $0 \%$ & $100 \%$ & 10.437 & 0.015 \\
\hline 1-5 Years & $20 \%$ & $80 \%$ & & \\
\hline 5-10 Years & $40 \%$ & $60 \%$ & & \\
\hline$>10$ Years & $52.6 \%$ & $47.4 \%$ & & \\
\hline
\end{tabular}

The engagement and participation in the activities related to the integration of science are included in the experience. Although many activities have been conducted regarding the integration of science, many lecturers may not participate in them. Many still ignore the existence of the university's guidelines for the integration of science and religion. As shown in Table 5 , the data show that $50.4 \%$ of lecturers perceive that the university does not have the guidelines while the other $49.6 \%$ of them agree to the existence of the guidelines. Our FGD also reveals that several lecturers teaching Islam and Science's subject stated the absence of UIN Jakarta's guideline of integrating science, which makes them unclear about the university's concept and policy. That most lecturers do not know about the guidelines may raise the issue of ineffectiveness of the socialization and internalization of the guidelines to lecturers, students, and staff.

Table 5. UIN Jakarta has the guidelines of science integration

\begin{tabular}{|c|c|c|c|}
\hline No & Category & Frequency & Percentage \\
\hline 1 & $\begin{array}{l}\text { Strongly } \\
\text { disagree }\end{array}$ & 6 & $4.1 \%$ \\
\hline 2 & Disagree & 68 & $46.3 \%$ \\
\hline 3 & Agree & 60 & $40.8 \%$ \\
\hline 4 & $\begin{array}{l}\text { Strongly } \\
\text { agree }\end{array}$ & 13 & $8.8 \%$ \\
\hline Tot & & 147 & $100 \%$ \\
\hline
\end{tabular}

Many lecturers perceive that the socialization of science integration has been sufficient. The data (table 6 ) show that $68.7 \%$ of lecturers positively perceive that UIN Jakarta has socialized its concept and policy of integration of science to lecturers, while others (31.3\%) disagree with the statement. From the above data, it seems that socialization has not reached all the university's lecturers, and compared with the data on the existence of guidelines, the socialization itself may still be ineffective. This corresponds to the research finding by Sayuti and Rahiem that "the socialization of paradigms and concepts development of science integration in each UIN is still a problem" (2020). Despite this, Sayuti \& Rahiem (2020) reveal that UIN Jakarta lecturers' knowledge about their university paradigm and concept of science integration is higher than that of UIN Malang lecturers. Nevertheless, socialization programs of the integration of science should be increased, both qualitatively and quantitatively.

Table 6. UIN Jakarta has socialized the concept and policy of science integration to lecturers

\begin{tabular}{|c|c|c|c|}
\hline No & Category & Frequency & Percentage \\
\hline 1 & $\begin{array}{l}\text { Strongly } \\
\text { disagree }\end{array}$ & 7 & $4.8 \%$ \\
\hline 2 & Disagree & 39 & $26.5 \%$ \\
\hline 3 & Agree & 84 & $57.1 \%$ \\
\hline 4 & $\begin{array}{l}\text { Strongly } \\
\text { agree }\end{array}$ & 17 & $11.6 \%$ \\
\hline \multicolumn{2}{|c|}{ Total } & 147 & $100 \%$ \\
\hline
\end{tabular}

Experience includes not only the teaching duration at UIN Jakarta but also leadership experience. Here we find that those figures who experienced as the university's functionaries among senior academia tend to have different conception from others. From the life experience of professors scrutinized in this study, there is a tendency to formulate the practical and strategic implementation of integration of science among them. This is evident in the conception of integration among Azyumardi Azra, M. Atho Mudzhar, Dede Rosyada, and Abuddin Nata. As has been known, Azyumardi Azra is undoubtedly the prominent architect of IAIN's transformation into UIN Jakarta. Before being elected as the two 
rectorial periods (1998-2006), he was the vicerector for academic affairs. After being the rector, he held the position of director of Graduate School at UIN Jakarta (2006-2015). M. Atho Mudzhar held many strategic positions at the Ministry of Religious Affairs, such as the director of Islamic Religious Education at School (19911994), the director of Islamic higher educational institution (1994-1996) and head of Board of Religious Research and Training (2002-2008), as we as the rector of UIN Sunan Kalijaga Yogyakarta (1996-2001). Dede Rosyada also held some important positions such as the dean of Faculty of Education and Teacher Training (2005-2011), the director of Islamic higher educational institution, the Ministry of Religious Affairs (2011-2014), and the rector of UIN Jakarta (2015-2019). Abuddin Nata also became the vice-rector for general administration and finance (1998-2006) and Dean of Faculty of Dirasat Islamiyah, UIN Jakarta (2008-2015). While Azyumardi Azra's conception of science integration is closely related to institutional development, Atho Mudzhar's conception attempts to enrich and diversify integration forms. While Mulyadi Kartanegara mainly deals with the philosophical foundation, Dede Rosyada's and Abuddin Nata's conception concentrates on implementing curriculum and learning process. With the leadership and managerial experience, most academia tends to have strategic and practical ideas concerning science integration. Thus, experience has become an essential factor that influences the conception of integration.

Another individual factor is expertise which is closely related to experience (Beck, 2015). Expertise may refer to the achievement of knowledge and skills in a particular field through learning, professional training, and practical experience. Some characteristics of expertise can be summarized as follow: experts excel mainly in their domains, perceive a significant, meaningful pattern, perform skills and solve a problem quickly, see a problem at a deep level, and spend much time analyzing a problem in their domains (Glaser \& Chi, 1988). Most indicators relate to one's area of expertise. Thus, a simple indicator of expertise is a formal qualification gained by academia.

Along with its transformation, various fields of specialization have developed at UIN Jakarta with its 78 departments under twelve faculties and the graduate school. All groups of science, including religious sciences, natural sciences, the humanities, social sciences, formal sciences, and applied sciences, have been provided, and the educational background of lecturers has been diverse. Therefore, lecturers' fields of expertise have been diverse, although some have little experience in science integration. While it is true that senior academia engaged in the formulation of integration of science at UIN Jakarta were generally trained in religious sciences, each has his/her field of specialization in religious sciences. Furthermore, many lecturers with a background in natural and social sciences have participated in it. For instance, Mulyadhi Kartanegara specializes in Islamic philosophy, Azyumardi Azra specializes in Islamic history, Atho Mudzhar is well-trained in the sociology of Islamic law Abuddin Nata and Dede Rosyada are experts in Islamic education. Thus, their field of expertise has characterized their conceptions of integration of science. While Kartanegara's characteristic of integration of science is mystical-philosophical, others' characteristics are likely to be practical and strategic. Furthermore, some of those who have expertise in natural sciences with less experience in the engagement of integration programs might be close to a minimum form. The most striking difference is certainly between experts and lecturers in general.

In sum, two factors affect the plural conceptions of science integration at UIN Jakarta, namely institutional and individual 
factors. The institutional factor provides the context for the differences in individual factors, mainly experience and expertise among lecturers and academia at UIN Jakarta.

\section{Conclusions}

Three types of the conception of sciencereligion integration have developed and coexisted at UIN Jakarta: the official conception, senior academia's conception, and general lecturers' conception with its formulation and emphasis. Except for some lecturers, they reject an Islamization of science while promoting the reintegration of sciences. Despite this, they generally share some similarities regarding the epistemological aspect, namely God as the sole source of all sciences, the rejection of dichotomy between general sciences and religious sciences, open and dialogic paradigm, and unended process of rejection of the use of metaphor. These characteristics have become the sociological concept of science integration at UIN Jakarta. In addition to using a metaphor as the standard of examining the concept of science integration at Islamic universities, as shown in most previous studies, the monolithic understanding fails to show that the multiple conceptions developed and co-existed at an Islamic university. This study has revealed the failure. The institutional and individual factors contribute to affect the plural conceptions of science integration. The cultural context of UIN Jakarta, with its historically admitted renewal project and the individual factor, including mainly experience and expertise, have significantly influenced the plural conceptions. While many studies such as Rifai et al. (2014); Efrinaldi \& Taufiqurrahman (2020); Sayuti \& Rahiem (2020) have found the significance of the cultural context and environment of each university in influencing its paradigm and concept of science integration, this paper uncovers that the cultural context and individual factors mainly experience and expertise contribute to affect the plural conceptions of science integration at a university. More complex factors should be considered in future research on the dynamic and plural entity of science integration at Islamic universities.

\section{References}

Abdallah, S. S., Huseein, S., \& Hisham, N. A. (2011). The Experience of Islamization of Knowledge at the International Islamic University Malaysia: Successes and Challenges. In New Intellectual Horizons in Education (pp. 91-110). Gombak: IIUM Press. Retrieved from http://irep.iium.edu.my/id/eprint/14493

Abdullah, M. A. (2014). Religion, Science and Culture: An Integration, Interconnected Paradigm of Science. Al-Jāmi'ah: Journal of Islamic Studies, 52(1), 175-203. https://doi.org/doi:

10.14421/ajis.2014.521.175-203

Ahsan, M. A., Shahed, A. K. M., \& Ahmad, A. (2013). Islamization of Knowledge: An Agenda for Muslim Intellectuals. Global Journal of Management and Business Research Administration and Management, 13(10), 32-42.

Akbarizan. (2014). Integrasi Ilmu: Perbandingan antara UIN Suska Riau dan Universitas Ummu Al-Qura Makkah. Riau: SUSKA Press.

Azra, A. (2005). Reintegrasi Ilmu-ilmu dalam Islam. Zainal Abidin Bagir, Jarot Wahyudi, dan Afnan Anshori (ed) Integrasi Ilmu dan Agama: Interpretasi dan Aksi. Bandung: Mizan in collaboration with Masyarakat Yogyakarta untuk Ilmu dan Agama and UIN Suka Press.

Azra, A. (2013). Islamic Education and Reintegration of Sciences: Improving Islamic Higher Education. Media Syariah, 263-270.

Beck, S. (2015). The Problem of Expertise: From Experience to Skilful Practices to Expertise, 
Ecological and Pragmatist Perspective. European Journal of Pragmatism and American Philosophy, 7(1), 346. https://doi.org/10.4000/ejpap

Bigliardi, S. (2014). The Contemporary Debate om the harmony between Islam and Science: Emergence and Challenges of a New Generation. Social Epistemology: A Journal of Knowledge, Culture and Policy, $28(2)$, 167-186. https://doi.org/https://doi.org/10.1080/02 691728.2013.782583

Çoruh, H. (2020). Relationship Between Religion and Science in the Muslim Modernism. Theology and Science, 18(1), 152-161.

https://doi.org/https://doi.org/10.1080/14 746700.2019 .1710355

Darda, A. (2015). Integrasi Ilmu dan Agama: Perkembangan Konseptual di Indonesia. Jurnal At-Ta'dib, 10(1), 33-46.

Efrinaldi, A. T., \& Taufiqurrahman. (2020). The Paradigm of Science Integration in Islamic University: The Historicity and Development Pattern of Islamic Studies in Indonesia. Madania: Jurnal Kajian Keislaman, $\quad 24(1), \quad$ 97-108. https://doi.org/10.29300/madania.v24i1.3 326

Fanani, M., Solokhan, \& Karnadi. (2014). Transformasi Paradigma dan Implikasinya pada Desain Kurikulum Sains: Studi pada UIN Syarif Hidayatullah, UIN Sunan Kalijaga, dan UIN Maliki. Semarang: UIN Walisongo Semarang.

Glaser, R., \& Chi, M. T. H. (1988). "Overview", M. T.H. Chi, R. Glaser, and M. J. Farr (eds) The Nature of Expertise $(\mathrm{xv}-\mathrm{xx})$. New Jersey: Lawrence Elbaum Associates Publishers.

Hanifah, U. (2018). Islamisasi Ilmu Pengetahun Konteporer: Konsep Integrasi Keilmuan di Universitas-Universitas Islam Indonesia. Tadris, 13(2), 273-294. https://doi.org/10.19105/tjpi.v13i2.1972.
Hashim, R., \& Abdallah, S. S. (2013). Islamization of Human Knowledge in Theory and Practice: Achievements, Challenges, and Prospoects in the IIUM Contexts. IIUM Journal of Educational Studies, 1(1), 1-12.

Hidayat, S. (2017). Konsep Integrasi Agama dan Sains: Studi Komparatif Syed Muhammad Naquib Al-Attas dan Mulyadhi Kartanegara. BA Sub-Thesis. Faculty of Ushuluddin, UIN Syarif Hidayatullah Jakarta.

Iswantir, M. (2018). Context of Scientific and Institutional Renewal in Islamic Higher Education (PTKI): A Study on Azyumardi Azra's Thought (1998-2015). Madania: Jurnal Kajian Keislaman, 22(2), 239-252.

Jabali, F., \& Khitam, H. (2014). Muqaddimah Integrasi Ilmu. Jakarta: UIN Press.

Kaplan, R. M., \& Saccuzzo, D. P. (2005). Psychological Testing: Principles, Application, and Issues. Belmont: Thomson Wadsworth.

Kartanegara, M. (2005). Integrasi Ilmu: Sebuah Rekonstruksi Holistik. Jakarta: UIN Jakarta Press dan Arasy Mizan.

Keputusan Direktur Jenderal Pendidikan Islam, Pub. L. No. 2498 (2019). Pedoman Implementasi Integrasi Ilmu di perguruan Tinggi Keagamaan Islam (PTKI). Jakarta : Direktorat Jenderal Pendidikan Islam Kementerian Agama Republik Indonesia.

Keputusan Rektor UIN Syarif Hidayatullah Jakarta, Pub. L. No. 843 (2017). Pedoman Integrasi Ilmu pada UIN Syarif Hidayatullah Jakarta. Jakarta: UIN Syarif Hidayatullah Jakarta.

Kusmana. (2014). The integration of knowledge and UIN Syarif Hidayatullah Jakarta. Islamika Indonesiana, 1(2), 19-36.

Kusmana, et al. (2006). Integrasi keilmuan UIN Syarif Hidayatullah Jakarta menuju Universitas Riset. Jakarta: PPIM dan UIN Jakarta Press. 
Miftahuddin. (2016). Integrasi Pengetahuan Umum dan Keislaman di Indonesia: Studi Integrasi Keilmuan di Universitas Islam Negeri di Indonesia. Attarbiyah: Journal of Islamic Culture and Education, 1(1), 89118.

https://doi.org/10.18326/attarbiyah.v1i1.8 9-118

Miftahuddin. (2019). Model-model Integrasi Ilmu Perguruan Tinggi Keagamaan Islam: Studi Multi Situs pada UIN Jakarta, UIN Yogyakarta, dan UIN Malang. Semarang: Diandra.

Mudzhar, M. A. (2018). The integration of science and religion: in search of a paradigm. Jakarta: Senate of Syarif Hidayatullah State Islamic University Jakarta.

Muslih, M. (2006). International Institute of Islamic Thought (IIIT) - USA: a project of Islamic Revivalism. Leiden University.

Naim, N. (2018). Mystico-Philosophy: The Integration Epistemologies of Mulyadhi Kartanegara. Episteme, 13(2), 361-379. https://doi.org/10.21274/epis.2018.13.2.3 61

Nata, A. et al. (2003). Integrasi Ilmu Agama dan Ilmu Umum. Jakarta: UIN Jakarta Press.

Nata, A. (2019). Respons Intelektual Muslim Indonesia terhadap gagasan Islamisasi Ilmu Pengetahuan dan Relevansinya terhadap Tantangan Era Milenial. Ta'dibuna: Jurnal Penidikan Islam, 8(2), 199-222. https://doi.org/10.32832/tadibuna.v8i2.22 250 .

Obaidullah, M. (2010). The Role of Universities Towards Islamization of Knowledge: The IIUM an a Model. Bangladesh.

Peraturan Menteri Agama, Pub. L. No. 17 (2014). Statuta UIN Syarif Hidayatullah Jakarta. Jakarta: Kementerian Agama Republik Indonesia.
Rifai, N. et al. (2014). Integrasi Keilmuan dalam Pengembangan Kurikulum di UIN seIndonesia: Evaluasi Penerapan Integrasi Keilmuan UIN dalam Kurikulum dan Proses Pembelajaran. Tarbiya: Journal of Education in Muslim Society, 1(1), 14-34.

Ro'up, M. et al. (2019). Criticism of Knowledge Integration in Non-Islamic Studies Students' Disserttion in State Islamic University. Dialog, 42(2), 234-251.

Rosyada, D. (2016). Islam dan Sains: Upaya Pengintegrasian Islam dan Ilmu Pengetahuan di Indonesia. Jakarta: RM Books.

Sayuti, W., \& Rahiem, M. D. (2020). A Comparison of Science Integration Implementation in Two State Islamic Universities in Indonesia. Madania: Jurnal Kajian Keislaman, 24(1), 109-120. https://doi.org/10.29300/madania.v24i1.3 293

Siregar, P. (2014). Integrasi Ilmu-ilmu Keislaman dalam Perspektif M. Amin Abdullah. Miqot: Jurnal Ilmu-Ilmu Keislaman, 38(2), 335-354. https://doi.org/10.30281/miqot.v38i2.66

Sofyan, A., Fauzan, \& Sayuti, W. (2018). he Pattern of scientific and Islamic Integration: the Implementation of Curriculum study program bades international Qualification Framework. Tarbiya: Journal of Education in Muslim Society, 5(2), 212-224. https://doi.org/10.15408/tjems.v5i2.1110 2. 